удк 7.03(438+477.81)

Liubov Krailiuk

кандидат мистецтвознавства

Рівненський державний гуманітарний

університет, м. Рівне

https://orcid.org/0000-0001-6232-7533

\title{
Rivne Artistic Textile School : formation, evolution, personalities
}

Анотація. Український художній текстиль від 60-х років минулого сторіччя став темою наукових праць С. Сидорович, А. Жука, Я. Запаска, 3. Чегусової, Т. Печенюк, Г. Кусько, Є. Шимчук, З. Шульги, Д. Боб'як, О. Ямборко. У історичному розрізі регіональні аспекти народного ткацтва досліджували О. Никорак, Т. Лупій, О. Луковська, О. Мойсюк та ін. Важливою фундаментальною працею, у якій розглянуто запропоновані проблеми, став 5 том «Історії декоративного мистецтва України» виданий Інститутом мистецтвознавства, фольклористики та етнології ім. М. Т. Рильського Національної академії наук України (2016). У ньому відзначено бурхливий розвиток текстильного мистецтва в Україні в 1990-х рр. і, особливо, з 2000-х рр., та розглядається у загальних рисах доробок рівненських та львівських мисткинь М. Токар, І. Токар, Т. Лукашевич та О. Охримик. Окремі аспекти творчості рівненських майстринь та становлення школи висвітлено А. Ніколаєвою, Н. Космолінською, О. Сташуком, І. Токар та ін. Однак комплексне дослідження становлення Рівненського текстильного мистецького осередку та проблем розвитку школи на сучасному етапі не здійснювалося, що підтверджує важливість пропонованої праці.

Метою дослідження $\epsilon$ виявлення соціокультурних передумов та особливостей становлення рівненської школи художнього текстилю; коротка характеристика творчості її найважливіших персоналій; визначення основних проблем та шляхів розвитку. Методологія базується на комплексному підході, що включає культурологічний, структурний аналіз та мистецтвознавчу інтерпретацію, що дозволило системно розглянути рівненське мистецтво тканини останніх десятиліть як цілісне мистецьке явище. Наукова новизна полягає у зверненні до регіональних 
особливостей сучасного текстильного мистецтва Рівного. Результати. Художній текстиль в усій різноманітності своїх втілень протягом останніх десятиліть постає на мистецькій мапі Рівного як поле для пошуків нової естетики та свіжого погляду на дійсність. Ця традиційно декоративна галузь щораз активніше тяжіє до образотворчості і може у своїх вершинних проявах претендувати на дослідження сучасного стану соціуму і людини. Важливим стимулом для розвитку художнього текстилю Рівненщини, попри слабкість інституційної підтримки особливо в останні роки, стало запровадження та функціонування фахової мистецької освіти. Нові художні смисли кристалізуються у процесі демократичної конкуренції між творчими ідеями майстринь різних поколінь, що вказує на формування школи художнього текстилю. Серед інших видів мистецтва саме текстиль найширше представлений на міжнародних виставкових заходах, в тому числі і доробком молодшої генерації майстринь.

Водночас слід відзначити проблему слабкої інституалізації українського сучасного мистецтва на регіональному рівні, першочергово вона виявляє себе на рівні музеєфікації артефактів, адже проблема репрезентації у сучасному світі виходить на перший план. Щодо текстильного мистецтва Рівненщини, то найбільш гостро стоїть питання відсутності централізованої акумуляції сучасних творів, які зберігаються в майстернях художниць, - що ускладнює повноцінне функціонування мистецьких висловлювань, їх вивчення та інтерпретацію.

Ключові слова: художній текстиль, Рівне, мистецька школа, спадкоємність.

$\mathrm{R}_{\mathrm{is}}^{\mathrm{e}}$ elevance of the research topic. Nowadays cloth art of Rivne region is developing more active than other kinds of art notionally named arts and crafts. This large-scale process is presented at numerous Ukrainian and international art reviews and demonstrates not only classical tapestries and batics but many up-to-date derivative textile forms. Thus it is becoming the object of research interest enriching horizontal measurements of Ukrainian cultural and art space. New names appear in the process of cloth art development in the end of the 20th and the beginning of 21th centuries. The author interprets these names as a young generation of Rivne artists. The subject-matter of this study is a constituent of complex research of Rivne State University for the Humanities Ukrainian art in the context of European art-space: history discourse and postmodern challenges»(0116 U 007707). 
Since the 1960s Ukrainian artistic textile has been researched by S. Sydorovych, A. Zhuk, Ya. Zapasko, Z. Chehuseva, T. Pecheniuk, H. Kusko, Ye. Shymchuk, Z. Shulha, D. Bobiak, O. Yamborko [1], O. Nykorak, T. Lupii, O. Lukovska, O. Moisiuk [6] studied regional features of folk weaving in history aspect. The fifth volume of The History of Ukrainian ornamental art published by M. T. Rylsky Institute of Art, Folklore Studies and Ethnology Institute of National Academy of Sciences of Ukraine is the important fundamental study where the researched issues are considered (2016). This volume presents the contribution of Rivne and Lviv artists Marta Tokar [2, 250; 2, 477], Ivanna Tokar [2:240, 241, 271, 477, 479], Tetiana Lukashevych [2:276, 312, 477, 478], and Olena Okhrymyk [2:238, 248, 252] in general features. Separate aspects of Rivne artists' creative work and school development are considered by A. Nikolaieva [7], N.Kosmolinska [4], O. Stashuk [8], I. Tokar [10], L. Krailiuk [5] etc. In modern times the complex research of Rivne art textile establishment and the issues of school development have not been presented that proves the importance of this paper.

This study aims to highlight social and cultural preconditions and features of Rivne Artistic Textile School establishment, give a short characteristic of its outstanding people creative work, and determine basic issues and ways of the development.

Research development. In Rivne region different techniques of linen, wool, hemp products manufacturing have been developing since ancient times. Such unique for Volyn and Polissia phenomena as linen serpankove weaving took place and were researched by O. Nykorak, L. Kostiuk, I. Lokshuk. The artists (K. Serna, L. Pikina, L. Zadvorna, L. Tymofieienko, B. Liashchuk, O. Kopot, O. Yevchuk, H. Bil, Ph. Hirenok, L. Sokolova, I. Havrylova, P. Drahunov, V. Polunova, O. Loktiev, S. Volkov, O. Bohatyrova, N. Duhovska [6, 34]) worked in the period of the $1960 \mathrm{~s}$ and almost till the end of the 21th century and their creative work was connected with Rivne linen factory. L. Zadvorna, L. Tymofieienko, and B. Liashchuk used traditional for Volyn Polissia combination of natural silver and bleached linen sometimes with wide red and narrow black stripes to make rushnyk and cloth fabric [2:302]. The artistic studio head of Rivne non-wooven materials factory (1975 - 1988) the Honored Artist of Ukraine Alevtyna Yelsukova was involved to fabric art of this period. Her batic works (Osin, Osinni sutinky, Karpaty) principally with flower and landscapes motives were repeatedly presented at Ukrainian and regional exhibitions. Artistic weaving craftswomen T.Lukashevuch and P.Lypova were engaged to 
Rivne regional organization of Ukrainian artist union beginning from the 1970s of the last century. The author points out that these craftswomen have a significant experience in the field of monumental art.

P.Lypova, who has lived in Rivne since 1970, was born in the village of Dzhuriv of Sniatun district in Ivano-Frankivsk region. After graduation from Vyzhnytsk Artistic College (Department of Artistic Weaving) she worked in the school in the village of Verenchanka in Zastavnian district of Chernivtsi region. After that she studied in Lviv State Institute of Applied and Decorative art (Faculty of Clothing Design), where vocational disciplines were taught by M.Tokar. Hutsul bright color scheme makes P.Lypova artistic textile palette different. Bright yellow, green, red, principally warm tones create energetic and optimistic images generated by natural and architectural motives. P.Lypova got an interesting experience in the process of long stage outfit projecting (1973-1980) for Honored Dance Ensemble Polisianka and drafting of two woven outfit for choir of Rivne City Cloth House.

Landscape and phytomorphic textile combinations of tapestries Tysha (1980), Doroha v horakh (1989), Soniashnyky (2001), Misiachna nich (2017) present certain stylized reality. Artist's creative work includes abstracted images based on the tone contrast relevant to sensitive interpretation of tragic and philosophy issues as for example tapestry Chornobul (1988) reveals. Monumental tapestry Rivne is a native town with heraldic compositional centre and architectural motives that decorates conference room in Rivne City Council is combined by delicate warm green shades. The author points out that heraldic work Tryzub (2014) is interesting because of its expressive tectonic form and emotional color scheme. The artist repeatedly participated in the international plain-airs in Dzintara (Lithuania) and she has solo exhibitions in Rivne, Lutsk, Ternopil, and Kyiv. Her tapestries decorate interiors of Austria, Finland, Canada, USA and other countries.

The field of artistic fabric was given a new development impulse in 1995 due to the foundation of the Department of Ukrainian Studies (now Department of Arts and Crafts) in Rivne State University for the Humanities. Marta Tokar and Ivanna Tokar who are the famous artists from Lviv were invited to organize vocational teaching process. Ivanna Tokar developed the author's programmes for such disciplines as Plastic, Composition, Special Composition, Work with Material taught for students till now. Lviv artist Olena Okhrymyk and Tetiana Lukashevych participated in teaching of the specialty in Rivne State University for the Humanities 
who has been teaching in Art School of Rivne Palace of Children and Youth for a long period of time.

In the field of Rivne artistic fabric development leading role belongs to successor of artist's dynasty Ivanna Tokar. Cultivating of creative individuality was started in the family surrounding and later it was continued and polished in specialty sphere in I.Trush Lviv State College of Decorative and Fine Arts (1980 - 1984) and Lviv State Institute of Applied and Decorative Arts (now The Lviv National Academy of Arts). The teachers were L. Shchur, V. Patyk, M. Tkachenko, B. Buriak, I. Shumskyi. Textile creative works details were mastered by Ya.Bodnar, Ye. Fashchenko, O. Minko. After Institute graduation she worked in Lviv Artistic and Manufacturing Integrated Plant. She took part in complex design interior of S. Krushelnutska Lviv Memorial Museum with Orest Skop [4:74].

Besides researching of curriculums I.Tokar dealt with the studying process management, technical questions about the purchase and settings of weaving machine, workrooms equipment (for example, the threads were given by The Lviv National Academy of Arts). At the same time with lecture activities the artist continued to develop her own creative work. In 1997 I.Tokar became the recipient of a prize in the first international exhibition Dialogue in Moldova, in 2000 she got Ahnieshki Sinkevych's prize for the tapestry Birth [4:76]. Artist solo exhibition took place in Europe and Asia: 1992 (Kyiv), 1993 (Beer-Sheva, Israel), 1996 and 1997 (Lviv), 1999 (International Art Feast in Skimpton and Bredford, England), 2000 (Wroclaw), 2001 (Zgozhulets, Poland), 2003 (Helsinki), 2002 and 2008 (International Symposium of Fiber Art WT Kowary, Kamienna Hura, Poland) [4:78].

The author states that I.Tokar art experience is very interesting in the field of material implementation for stage outfit. Basing on folk motives interpretation in the 1990s she participated in modern clothing set making sketched by M.Tokar for the ensemble of violinists led by O.Stepanova, the composer, Ukrainian honored creator, head of the Department of Folk Instruments in Rivne State University for the Humanities. I. Tokar's creative work is characterized by a high plastic culture and compositional order in all textile techniques among which tapestry and batic are stressed. Discourse about modern issues are interpreted in such different theme branches as sacredness presented in diploma paper tapestry Kriz viky, spiritual transformations, urban science, inner experience. In her interpretations I. Tokar never gives 
specific and complete answer the eternal questions or modern issues. Her works visual intonations are relaxed, need to be listened to attentively, syntonize for concentration and meditation (batic Moii vikna, 2010, textile triptych panel picture Chas, 2003 etc), invite the spectator to dip in heads-up play of associations through the interaction of different emotional conditions (tapestry Peredchuttia, 2003). This inner silence implemented in perfect compositional and color decisions creates original oasis in fussy cacophony of the modern city and reveals as a peculiar offer of alternative research for thoughtless consuming (tapestries Prostir, 1993, Vody pusteli, 2000). Researchers emphasize the artist's cultivating of the material in nature conditions $[3,907]$ that in certain way explains color scheme asceticism in the most part of her tapestries, batics, coverlets and other textile forms. Sometimes excellent nuance skills make artist's plastic experiments similar to sfumato. In integral visual and communicative utterances nature materials and color tones the artist prefers highlight the important semantic superposition that is environmental friendliness in different modern aspects.

Students' works led by the artist have not only high compositional culture but also variety of author's research. I. Tokar's most successful students are participants of international artistic textile exhibitions Olha Poberezhna and Olha Yarmoshevych, artistic textile craftswomen Oksana Halaichuk, Nataliia Piliuhina, Olena Havtura, Rivne famous art photographer Liudmyla Kostrutska, Strasbourg University master's student (Modern Art Faculty) Kateryna Prostrila, lead scene designer of Rivne Regional Academic Music and Drama Theatre Anna Piliuhina. O. Yarmoshevych got the third place in the nomination of Time Philosophy at the First International Symposium of Artistic Textile Teacher and Pupil (Lviv, 2017).

Similar theme and image basics are character features of T. Lukashevych's creative work. A. Nikolaeva states that her creative work is accepted in national artistic universe as the developing original, entire and bright artistic phenomenon [ 9, 2]. The researcher notes self-sufficiency of plastic structures and visual image harmony in her artistic experience. T. Lukashevych who is the great-granddaughter of the talented pedagogue, ethnographer and poet Ivan Kulish, the daughter of the writer and ethnographer Iryna Kulish-Lukashevych, graduated from Lviv State Institute of Applied and Decorative Arts where she was taught by K. Zvirynskyi, S. Koropchak, V. Ovsiichuk, Yi. Sadovskyi, V. Cherkasov. The artist had the experience of working in Knitwear Republic Fashion 
House of the Ministry of Clothing and Footwear Industry in USSR, in manufactory studio of Rivne Art Fund. In textile field the artist made a folding screen for restaurant Turyst and series of stage outfits interpreting Polissia folk customs (Rahishnia zoria, Sribnyi peredzvin, Barvy Polissia, Serpankovi mrii) or using free associations (Kosmichna rapsodiia) [7, 6]. Since the 1990s tapestries and batic have been holding price of place in T. Lukashevych creative work. Despite of the subject matter variety (phytomorphic motives, landscapes and Ukrainian ornament interpretation) the artist singled out archaic direction. Being amazed she interprets different cultural layers of the last epochs, till art symbols of Christianity and mythological motives (hot batic Pradavni znaky, 2006, triptych Zahusty nas, Angele Bozhyi, 2010, tapestry Stvorennia svity, 2015). Her favorite materials are linen and wool often used with natural dyes. Recently some artist's works inspired by archaic impulse form individual ontology and motivate spectator to this process (tapestry Plyn chasu - plyn zhyttia, 2010, panel picture Kyshenky moiei pamiati na polotni zhyttia, 2011).

O. Okhrymyk's artistic textile has another individual plastic code where the color principle is a significant characteristic. The artist developed her style in Lviv. The artist got weaving skills secrets from $\mathrm{M}$. Tokar and paintings lessons were taught by K. Zvirynskyi. Due to the existence of alternative exhibition space and meetings with progressive intellectual painters the young artist was aware of late modern paintings and other expressions of recusance. This unique experience was expressed in artist's painting and textile searching where the color and shape are always stressed. O. Okhrymyk is famous for her achievements in the field of interior fabrics and stage folk outfit interpretation. The subject matter of her textile works and paintings is focused on nature motives interpreted through the expressive color and compositional decisions of figurative approach, for example, made in co-authorship with O. Rybotytska quadrilateral tapestry Lis or miraculous series of Nadsluchia landscapes. O. Okhrymyk's tapestry image order is characterized by powerful emotional sounding and delicate drama through the unique color combinations. Lviv color scheme influence can be noticeable in creative work of young artists led by O.Okhrymyk (T.Hrushnytska's tapestry Stykhiia, V.Bordzekhovska's Tanets).

Rivne textile section is gradually getting wider because of new young artists. Each of them develops her own artistic language. For example, A.Kliapovska creates monumental panel picture using balance 
of such different artistic techniques as fabric painting, combine painting, felting, textile plastic arts. She also practices in classic tapestry and batic. O.Okhrymyk's student continued art studying at Master's Degree in The Lviv National Academy of Arts for guidance of T.Pecheniuk and H.Kusko. The artist demonstrated her textile works at The Fifth Ukrainian Triennial of Artistic Textile in Kyiv, exhibitions of mini-tapestry in the gallery Dzyga (Lviv) and international exhibitions in Germany and Poland. The author states that her works are dynamic according to the composition and monumental in the scope of sense content (Moie sertse $\mathrm{v}$ doloniakh is non-woven materials, gold foil, scraped paper, graphics, and application; Znak svitla is a tapestry). Philosophy hints are visible even in mini-tapestry (Kliuchyk shchastia).

O.Halaichuk is a participant of Ukrainian exhibitions in Kyiv, Dnipro, Chernivtsi and The Fifth Triennial of Artistic Textile in Kyiv. The artist demonstrates delicate skills in using contrast and nuance means, intellectual compositional play (Harmoniia svidomosti is nonwoven materials, wool, paper; Rizdviana zirka is batic, lace). In her works the contrast between traditional and modern esthetic systems suggests for the spectator to feel time passing through the possibility of challenging emotions experience and probably to analyze or construct the own point of view. O. Halaichuk's works are distinguished because of its nobleness, deep interpretation and content of every separate art utterance.

O.Poberezhna participated in Artistic Textile Biennial twice (Krosno, 2014, 2016), Exhibition of Arts and Crafts in Siedlce (Poland, 2005), Ukrainian Triennial of Artistic Textile in Kyiv (2010-2011) and other numerous Ukrainian exhibitions. She had solo exhibition in Rivne (2015). The artist successfully experiments in different techniques (batic, tapestry, fabric painting, application, and author's techniques) and developed the own recognized hand-writing that is gentle, womanish with the preference of lyric notes in work compositional order (Gold is a tapestry, collage, linen; Try kolory is a tapestry). O.Poberezhna's interpretations with textile materials are full of special power. Being limited in such non-figurative means as rhythm, color, material texture they visualize individual experience of sociability and artist's trust in world.

I. Tokar, T. Lukashevych are permanent participants of such international artistic textile reviews as International Biennale of Linen Fabric Z Krosna do Krosna (Poland, Krosno), Art Fiber Symposium WT Kowary, International Plain-Air Ekolohichnyi rakurs. The most important events where Rivne artists' works were demonstrated are Ukrainian 
Triennials of Artistic Textile (Kyiv, 2004-2016). I. Tokar's works were presented at the textile premiere in M.Bilas Museum (Truskavets, 2014) and exhibitions of artistic fabric painting Chervone i Chorne and Chervin $\mathrm{u}$ dialohu within the program of International Academic Conference Poland - Ukraine. Co-existing and Identity. Similarities and Differences on the Cultural Border that took place in Lviv Art Palace (2015). Since 1987 T. Lukashevych has been participating in 26 exhibition events that took place in Poland, Hungary, Slovakia, Russia, Estonia, Latvia, and Japan. Artist's solo exhibitions took place in Zbarazh, Lutsk, Bilostok, Liublin, Bilostok (Poland), and Dubno. These facts demonstrate rhetorical effectiveness of artistic utterances as the reactions to modern realities presented by Rivne artists of older and younger generations during last decades. Demonstration of textile works is held in Rivne where I. Tokar's (2003, 2015), T. Lukashevych's (1996, 2003, 2006, 2012, 2016), O.Okhrymyk's (2005) solo exhibitions were succeed.

The author identifies V.Dziobak's (Kyiv sponsor) private initiative as the worth one for uniting and efforts coordination with the aim of Rivne regional artistic weaving development. This initiative deals with the studio of traditional clothing renaissance Volynskyi serpanok in Radyvyliv that due to exhibitions becomes known in Ukraine. Under the conditions of postmodern situation with its unclearness of limits between art and reality, concentration on the process and wish to quote reconstruction activities can be considered as the important constituent of art space formation in separate contexts.

Simultaneously the author points out the issue of weak institutionalization of Ukrainian modern art on the local level. First of all it is revealed on the level of artifacts museification as the representation issue becomes the main one in the modern world. According to Rivne regional textile art the issue of centralized accumulation absence of modern works kept in artists' studios is the most important one. This makes art utterances function more complicated for its research and interpretation.

Artistic textile vocational school cooperation with Rivne Linen Factory (that existed till the 1990s) has interesting potential possibilities under the conditions of factors appearance that would let reanimate it or develop a new one. The author states that it can be the development of flax culture in Ukraine, expanding of enterprise ranges and other strategic structural initiatives.

Conclusions. Rivne Artistic Textile School became the original 
branch of Lviv Arts and Crafts School. Focusing on regional folk weaving traditions Rivne modern craftswomen developed a new and unique artistic phenomenon characterized by the variety of its expressions in the semantic content and shape-created aspect. Rivne art-space analysis through the decentralization of artistic processes demonstrates that the leading role definitely belongs to art fabric in this process. Moreover this trend is powerful enough and artistic textile is a counterweight factor to the traditional painting centrism of Ukrainian art (including art-market).

The next stage of the research aims to highlight imaginary system of separate art personalities. The study can be interpreted in such interdisciplinary aspects as cultural analysis, methodological points etc.

The author thanks I. Tokar, T. Lukashevych and P. Lypova for given materials and experts' opinion.

1. Боб'як Д. Дослідження українського художнього текстилю XX - початку XXI ст. Актуальні питання гуманітарних наук: 36. наук. праць молодих вчених Дрогобицького державного педагогічного університету ім. Івана Франка. Дрогобич. 2015. Вип. 12. С. 113-118.

2. Історія декоративного мистецтва України : У 5 т. / голов. ред. Г. Скрипник, НАН України ІМФЕ ім. М. Т. Рильського Київ, 2016. Т. 5. 546 с. +266 іл.

3. Історія українського мистецтва : у 5 т. / НАН України, ІМФЕ ім. М. Т. Рильського ; голов. ред. Г Скрипник, наук. ред. Т. Кара-Васильєва. Київ, 2007. Т. 5 : Мистецтво XX століття. 1048 с., іл. С. 900.

4. Космолінська Н. Мистецтво нюансую Творчістю та наукою утвержду$\epsilon M /$ упор. С.І. Шевчук. Рівне : Волинські обереги, 2013. С. 74-79.

5. Крайлюк Л. Колористичний аспект творчості Олени Охримик. Bicник Закарпатського художнього інституту : 36. наук. праць / Ред. кол.: Небесник I. І. та ін. Ужгород: Закарпатський художній інститут, 2015. Вип. 7. С. 60-66.

6. Мойсюк О. Інтерпретації традицій поліського народного ткацтва у виробничих процесах Рівненського та Житомирського льонокомбінатів. Мистецький простір України: історія та сучасні виклики: Матеріали Всеукр. наук.-практ. конф. до 110-річчя з дня народження Ніла Хасевича / упоряд. О. А. Сташук, Л. В. Крайлюк]. Рівне: РДГУ, 2016. С. 33-42.

7. Ніколаєва А. Тетяна Лукашевич. Гобелен. Батик. Серія «Митці Рівненщини». Рівне : У фарватері істин, 2016. 84 с., іл.

8. Сташук О. Марта Токар - мисткиня за покликом серця. Вісник Львів- 
ської національної академії мистецтв. Львів : ЛНАМ, 2016. Вип. 28. C. 25-37.

9. Тетяна Лукашевич. Текстиль : Каталог Рівне : РООСХУ, 2011. 12 с., іл.

10. Токар I. Від традицій до новацій. Творчістю та наукою утверждуєм / упор. С.І. Шевчук. Рівне : Волинські обереги, 2013. С. 63-75.

\section{References:}

1. Bobiak, D. (2015). Research of Ukrainian artistic textile of the XX century and the beginning of the XXI century. Aktualni pytannia humanitarnykh nauk : mizhvuzivskyi zb. nauk. prats Drohobytskoho derzhavnoho pedahohichnoho universytetu im. Ivana Franka. Mystetstvoznavstvo, 12, 113-118. [In Ukrainian].

2. Skrypnyk, H. (Eds.). (2016). The history of Ukrainian decorative art. Kyiv : NAN Ukrainy IMFE im. M. T. Rylskoho. [In Ukrainian].

3. Skrypnyk, H. (Eds.). (2007). The history of Ukrainian art. Kyiv : NAN Ukrainy IMFE im. M. T. Rylskoho. [In Ukrainian].

4. Kosmolinska, N. (2013). The art of a nuance. Tvorchistiu ta naukoiu utverzhduiem. S. Shevchuk (Ed.). Rivne. [In Ukrainian].

5. Krailiuk, L. (2015). Coloristic aspect of Olena Okhrymyk's creative work. Visnyk Zakarpatskoho khudozhnoho instytutu, 7, 66-67. [In Ukrainian].

6. Moisiuk, O. (2016). Interpretation of Polesia folk weaving in manufacturing processes of Rivne and Zhytomyr linen factories. Mystetskyi prostir Ukrainy: istoriia ta suchasni vyklyky: Proceedings of Ukrainian scientific and practical conference timed to 110 years from Nil Khasevych's birthday. (pp. 33-42). Rivne: RSUH. [In Ukrainian].

7. Nikolaieva, A., \& Lukashevych T.(2016). Tapestry. Batic. Seriia «Myttsi Rivnenshchyny». Rivne: U khavateri istyn. [In Ukrainian].

8. Stashuk, O. (2016). Marta Tokar is an artist answering the call of the heart. Visnyk Lvivskoi natsionalnoi akademii mystetstv, 28, 25-37. [In Ukrainian].

9. Lukashevych, T. (2011). Textile: Prospectues. Rivne: ROOSKhU. [In Ukrainian].

10. Tokar, I. (2013). Vid tradytsii do novatsii [From the traditions to novations]. Tvorchistiu ta naukoiu utverzhduiem. S. Shevchuk (Ed.). Rivne. [In Ukrainian].

\section{ANNOTATION}

Liubov Krailiuk. Rivne Artistic Textile School : formation, evolution, personalities. Background. Since the 1960s Ukrainian artistic textile has been 
researched by S.Sydorovych, A.Zhuk, Ya.Zapasko, Z.Chehuseva, T.Pecheniuk, H.Kusko, Ye.Shymchuk, Z.Shulha, D.Bobiak, O.Yamborko, O.Nykorak, T.Lupii, O.Lukovska, O.Moisiuk studied regional features of folk weaving in history aspect. The fifth volume of The History of Ukrainian ornamental art published by $M$. T. Rylsky Institute of Art, Folklore Studies and Ethnology Institute of National Academy of Sciences of Ukraine is the important fundamental study where the researched issues are considered (2016). This volume presents the contribution of Rivne and Lviv artists Marta Tokar, Ivanna Tokar, Tetiana Lukashevych, and Olena Okhrymyk in general features. Separate aspects of Rivne artists' creative work and school development are considered by A.Nikolaieva, N.Kosmolinska, O.Stashuk, I.Tokar etc. In modern times the complex research of Rivne art textile establishment and the issues of school development have not been presented that proves the importance of this paper.

This study aims to outline social and cultural preconditions and features of Rivne Artistic Textile School establishment, give a short characteristic of its outstanding people creative work, and determine basic issues and ways of the development.

The methodology is based on the complex approach including cultural, structural analysis and art study interpretation. This has provided the possibility using a system way to consider Rivne cloth art of the last decades as a complete art phenomenon.

The scientific novelty concerns with regional characteristics of Rivne modern textile art.

Results. Since last decades artistic textile having huge variety of its presentation has been becoming the field for new esthetic research and new point of view according to the surrounding on Rivne artistic map. This traditional ornamental branch is getting closer to pictorial art and in perfect manifestations it can even pretend to research modern social and human being conditions. The implementation and function of vocational art education were the important motivation to develop Rivne region artistic textile despite of weak institutional support especially in recent years. This paper studies beginnings and current issues of Rivne Cloth Art School becoming. New artistic senses are polished in the process of democratic competition through craftswomen creative ideas of different generations. This fact demonstrates the formation of Rivne Artistic Textile School. It is textile that is presented at international exhibitions among other kinds of arts including contribution of younger generation craftswomen. Simultaneously the author points out the issue of weak institutionalization of Ukrainian modern art on the local level. First of all it is revealed on the level of artifacts museification as the representation issue becomes the main one in the 
modern world. According to Rivne regional textile art the issue of centralized accumulation absence of modern works kept in artists' studios is the most important one. This makes art utterances function more complicated for its research and interpretation. Artistic textile vocational school cooperation with Rivne Linen Factory (that existed till the 1990s) has interesting potential possibilities under the conditions of factors appearance that would let reanimate it or develop a new one. The author states that it can be the development of flax culture in Ukraine, expanding of enterprise ranges and other strategic structural initiatives.

Conclusions. Rivne Artistic Textile School became the original branch of Lviv Arts and Crafts School. Focusing on regional folk weaving traditions Rivne modern craftswomen developed a new and unique artistic phenomenon characterized by the variety of its expressions in the semantic content and shape-created aspect. Rivne art-space analysis through the decentralization of artistic processes demonstrates that the leading role definitely belongs to art fabric in this process. Moreover this trend is powerful enough and artistic textile is a counterweight factor to the traditional painting centrism of Ukrainian art (including art-market). The next stage of the research aims to highlight imaginary system of separate art personalities. The study can be interpreted in such interdisciplinary aspects as cultural analysis, methodological points etc.

Key words: artistic textile, art school, succession, evolution.

\section{АННОТАЦИЯ}

Любовь Крайлюк. Ривненская школа художественного текстиля: становление, эволюция, персоналии. Цель исследования состоит в выявлении социокультурных предпосылок и особенностей становления ривненской школы художественного текстиля; краткой характеристике творчества главных персоналий; определении основных проблем и путей развития. Методология базируется на комплексном подходе, включающем культурологический, структурный анализ и искусствоведческую интерпретацию, что позволило системно рассматривать ривненское искусство ткани как целостное художественное явление. Научная новизна состоит в обращении к актуальным региональным аспектам текстильного искусства Ривного.

Ключевые слова: художественный текстиль, художественная школа, преемственность, эволюция. 